\title{
Décimo Aniversario de Monseñor Romero
}

\author{
Revista Latinoamericana de Teología, \\ San Salvador, El Salvador.
}

El 24 de marzo de este afio se ha celebrado el décimo aniversario del asesinato y martirio de Monsefior Romero. La Revista Latinaamericana de Teologia, que tanto le debe en su inspiración, desea sumarse agradecidamente a las numerosas celebraciones de estos dias. Para ello publicamos tres textos que expresan quién fue y quién es Monsentor Romero.

El primero es de Ignacio Ellacuria, "Monsefior Romero, un enviado de Dios para salvar a su pueblo". Ellacuría lo escribió en 1980 pocos meses después del asesinato de Monseffor Romero. En él ofrece su visión teológica de Monsefior tras la que se esconde un profundo agradecimiento y admiración personal. "Monseñor ya se nos ha adelantado", solía decir. Si Rahner y Zubiri fueron decisivos para su propio pensamiento teológico y filosofico, Ellacurfa consideró a Monsefior Romero como el cristiano que más lo impactó en su fe. "Con Monseffor Romero Dios pasó por El Salvador", dijo en la homilia de la eucaristía celebrada en la UCA inmediatamente después de su asesinato. Sirva este artículo del mártir Ignacio Ellacuría para comprender mejor al mártir Monsefior Romero.

El segundo texto es una entrevista de don Pedro Casaldáliga, el 22 de marzo de este affo, tenida en el hospital de la Divina Providencia donde Monseffor derramó su sangre, que hemos tiulado "Monseffor Romero, un santo de todos y para todos". Don Pedro es antiguo y entraftable seguidor y admirador de Monsefior. Inmediatamente después del asesinato escribió el poema, ya clásico e imperecedero, "San Romero de América". Y la primera vez que abandonó Brasil, después de 17 aflos, fue para visitar la atormentada Nicaragua y para visitar aqư la tumba de Monseñor. A la entrevista afladimos dos poemas escritos en estos días en EI Salvador sobre Monseffor Romero y los mártires de la UCA. Sirva el testimonio de este obispo, profela y poeta, para cantar a Monseffor.

El tercero es una reflexión teológica de Jon Sobrino sobre la presencia de Monsenor Romero en la historia y en la fe: "Monseffor Romero, diez anos de 
tradición". Es un análisis leórico sobre esa presencia, en qué consiste, qué es lo que ha desencadenado y por qué lo ha desencadenado. Monschior Romero es visto desde la gran tradición pascual de Jesús, que la prosigue y la actualiza, y por ello, como Jesús, sigue presente en la historia generando tradición.

De esta forma la Revista Latinoamericana de Teología desea unirse a las celebraciones del décimo aniversario de Monsenor Romero, desea agradecer y honrar su vida, su obra y su pascua, desea cooperar a mantener viva la figura de Monseffor Romero y la tradición que ha generado. Desea especificamente seguir haciendo leología sobre Monsefior Romero y, sobre lodo, desde Monsefior Romero. 